\title{
PERFORMA SUKUK RITEL: SEBELUM DAN SAAT TERJADI PANDEMI COVID-19
}

\author{
Nurhayati Gustina \\ Universitas Islam Negeri Sunan Kalijaga, nurhayati.gustina2@gmail.com
}

\begin{abstract}
ABSTRAK
Sukuk merupakan suatu instrumen keuangan yang diterbitkan baik oleh swasta maupun pemerintah yang nantinya akan digunakan untuk membantu operasional perusahaan atau proyek. Sukuk negara ritel merupakan jumlah lembar sukuk negara ritel yang diperdagangkan di bursa. Sukuk negara ritel diterbitkan untuk membiayai defisit Anggaran Pendapatan dan Belanja Negara (APBN). Tujuan dari penelitian ini adalah untuk mengetahui apakah variabel harga sukuk SR008 dan SR-010 serta variabel makro ekonomi seperti BI Rate, Inflasi dan Nilai Tukar (Kurs) berpengaruh terhadap keputusan investor dalam meningkatkan performa Sukuk Ritel Negara pada sebelum dan saat terjadi pandemi. Analisis data yang digunakan dalam penelitian ini adalah menggunakan analisis model VAR (vector autoregressive) dan VECM (vector error correction model) yang di olah dengan program Eviews 10. Metode analisis yang digunakan dalam penelitian ini adalah analisis regresi data time series.

Hasil penelitian ini menunjukan bahwa performa sukuk ritel negara memiliki hubungan jangka panjang antar variabel Harga Sukuk Ritel, BI Rate, Inflasi dan Kurs terhadap performa sukuk negara ritel ini. Pada hubungan jangka panjang diketahui bahwa variabel BI Rate memberikan pengaruh positif terhadap performa sukuk ritel negara. Sedangkan dalam jangka panjang variabel Inflasi, Harga Sukuk Ritel Negara dan Kurs memiliki pengaruh negatif terhadap performa sukuk ritel negara. Hasil penelitian yang telah dilakukan menunjukan bahwa variabel harga memiliki pengaruh yang cukup signifikan dalam jangka pendek maupun jangka panjang antar variabel harga terhadap performa sukuk ritel negara itu sendiri. Sedangkan untuk variabel kurs, terdapat pengaruh jangka panjang terhadap sukuk ritel negara, tetapi tidak terlalu berdampak signifikan artinya variabel kurs mempengaruhi keputusan dan jika nilai kurs turun makan dapat mendorong investor untuk berinvestasi dalam sukuk negara ritel, sehingga performa sukuk ritel negara akan meningkat. Pada hasil uji Beda atau Paired Sample T-Test bahwa tidak terdapat perbedaan yang signifikan antara performa sukuk ritel negara sebelum dan saat terjadi pandemi.
\end{abstract}

Kata Kunci : Performa Sukuk Ritel Negara, BI Rate, Inflasi, Kurs.

\section{ABSTRACT}

Sukuk is a financial instrument issued by both the private sector and the government which will later be used to assist the operations of the company or project. Retail state sukuk is the number of retail state sukuk that are traded on the exchange. Retail state sukuk are issued to finance the deficit in the State Budget (APBN). The purpose of this study was to determine whether the price of sukuk variables SR-008 and SR-010 as well as macroeconomic variables such as the BI Rate, Inflation and Exchange Rate (Exchange Rate) had an effect on investor decisions in improving the performance of State Retail Sukuk before and during the pandemic. Analysis of the data used in this research is using VAR (vector autoregressive) and VECM (vector error correction model) analysis which is processed by the Eviews 10 program. The analytical method used in this study is regression analysis of time series data. 
The results of this study indicate that the performance of state retail sukuk has a longterm relationship between the variables of Retail Sukuk Price, BI Rate, Inflation and Exchange Rate on the performance of this retail state sukuk. In the long-term relationship, it is known that the BI Rate variable has a positive influence on the performance of state retail sukuk. Meanwhile, in the long term, the inflation variable, the State Retail Sukuk Price and the Exchange Rate have a negative effect on the performance of the state retail sukuk. The results of the research that have been carried out show that the price variable has a significant influence in the short and long term between price variables on the performance of the country's retail sukuk itself. As for the exchange rate variable, there is a long-term effect on state retail sukuk, but it does not have a significant impact, meaning that the exchange rate variable affects decisions and if the exchange rate drops, it can encourage investors to invest in retail state sukuk, so that the performance of state retail sukuk will increase. In the results of the Different or Paired Sample T-Test test that there is no significant difference between the performance of the country's retail sukuk before and during the pandemic.

Keywords: State Retail Sukuk Performance, BI Rate, Inflation, Exchange Rate.

Naskah diterima : 04-10-2021, Naskah dipublikasikan : 30-11-2021

\section{PENDAHULUAN}

Sejak merebaknya virus pandemi covid-19 pada awal tahun 2020 telah memberikan dampak serius pada hampir seluruh negara di dunia, termasuk Indonesia. Pengaruh yang ditimbulkan akibat pandemi ini tidak hanya pada satu bidang, namun hampir di seluruh aktivitas yang ada. Adanya berbagai pembatasan di suatu negara sudah tentu berimbas pada aktivitas ekonomi, salah satu aspek yang menjadi perhatian di tengah merebaknya virus corona adalah investasi. Selain masalah kesehatan pandemi covid-19 juga menimbulkan dampak terhadap investasi yang membuat masyarakat akan memilih untuk sangat hati-hati dalam membeli barang bahkan untuk melakukan investasi.

Banyak perusahaan menutup usaha atau mengurangi karyawannya. Selain dikarenakan pembatasan jumlah kehadiran dalam suatu tempat karena aturan social distancing demi menurunkan angka penularan kasus Covid-19, hal ini juga diakibatkan lantaran laba yang terbilang terjun bebas. Laba menurun karena konsumsi masyarakat menurun. Konsumsi menurun karena masyarakat lebih memilih untuk tinggal dirumah sebagai upaya preventif diri. Bahkan ketika ada isu PSBB (Pembatasan Sosial Berskala Besar) bursa saham langsung anjlok. IHSG anjlok $5 \%$ (lima persen) hingga BEI terpaksa menghentikan perdagangan sementara (trading halt). Hal tersebut tertuang dalam dalam surat nomor S-274/PM.21/2020 tanggal 10 Maret 2020 yang menyebutkan bahwa trading halt akan dilakukan selama 30 menit apabila IHSG anjlok lebih dari 5\% (Moh. Fadil,2020).

Berbeda dengan instrumen saham lainnya yang terkena dampak akan covid-19 ini, sukuk malah mampu bertahan dan tetap eksis di situasi seperti pandemi ini. Sukuk merupakan efek Syariah berupa sertifikat atau bukti kepemilikan yang bernilai sama dan mewakili bagian yang tidak terpisahkan atau tidak terbagi (syuyu'/undivided share) atas aset yang mendasarinya (Otoritas Jasa Keuangan, 2018).

Di Indonesia, pemerintah resmi menerbitkan sukuk negara ritel pada 25 Februari 2009 untuk mendukung APBN 2009.12 Jenis akad sukuk negara ritel yang akan diterbitkan adalah ijarah sale and lease back dengan underlying assets berupa barang milik negara berupa tanah dan/atau bangunan yang saat ini sedang digunakan oleh Depkeu. Sukuk negara ritel perdana yang diterbitkan memiliki tenor (jangka waktu) 3 tahun (jatuh tempo 25 Februari 2012) dengan nominal per unit Rp 1 juta dengan minimum pembelian sebesar Rp 5 juta dan kelipatannya serta tidak ada 
batas maksimum pembelian. Tingkat imbal hasil akan ditentukan satu hari sebelum tanggal penawaran. Imbal hasil sebesar 12\% itu akan dibayarkan secara bulanan (tiap tanggal 25).

Sejak pertama kali diterbitkan tahun 2008, penerbitan total sukuk negara telah mencapai Rp 1.044,71 triliun dan outstanding sukuk negara sampai 27 Februari 2019 mencapai 19\% dari total outstanding Surat Berharga Negara (SBN) sebesar Rp. 698,82 triliun (Aryani, 2019). Sukuk ritel merupakan salah satu instrumen sukuk negara yang ditujukan bagi individu Warga Negara Indonesia (WNI). Sukuk ritel terbit pertama kali tahun 2009 dengan diberi nama SR-001, dan sampai dengan tahun 2018, telah berhasil meraih investor sebanyak 243.364 orang dengan total akumulasi penerbitan sebesar Rp. 144,7 triliun (Aryani dalam Muhammad, 2019).

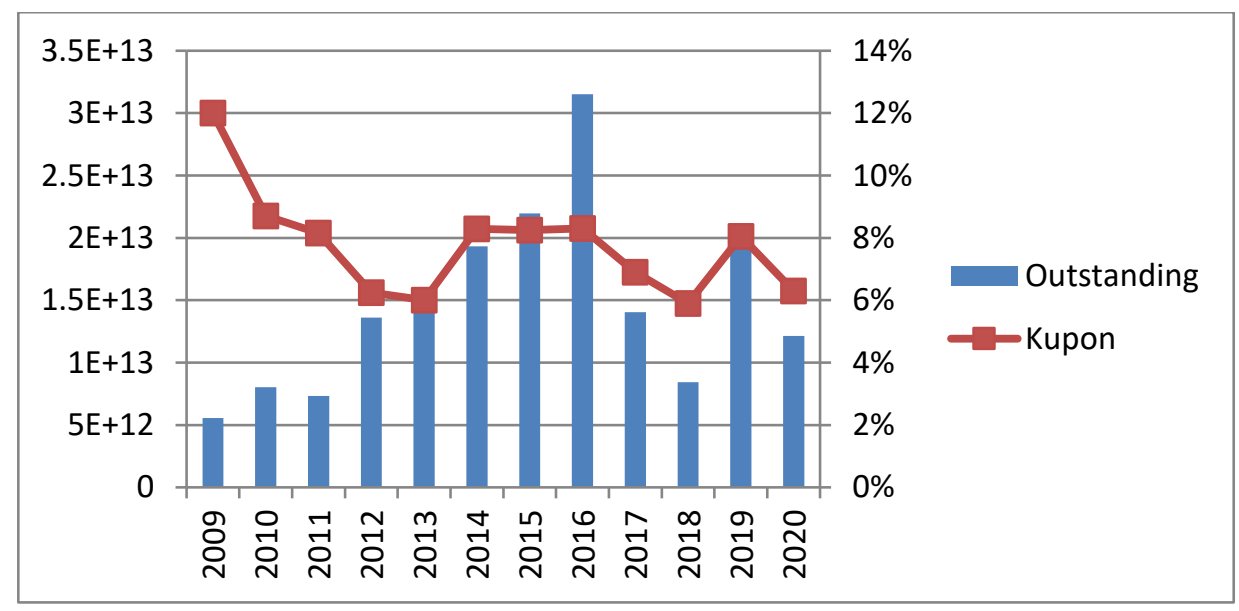

Gambar 1. Grafik Perkembangan Sukuk Ritel (Triliun, Rp)

Sumber : Kementerian Keuangan, Sukuk 2009 - 2020, Data diolah.

Sukuk pertama diterbitkan pada tahun 2009 yaitu SR-001 dengan tingkat imbalan 12,00\% memperoleh dana sebesar Rp. 5.56 triliun menggunakan akad ijarah sale and lease back dan tenor 3 tahun. Selanjutnya tahun 2010 pemerintah juga menerbitkan SR-002 dengan tingkat imbalan 8,70\% yang lebih rendah dari SR-001 dan memperoleh dana sebesar Rp. 8 triliun. Dengan tenor 3 tahun.

Dilihat dari tabel tersebut pertumbuhan sukuk ritel dilihat dari jumlah pembiayaan dan jumlah investornya memiliki grafik progres yang naik turun. Pertumbuhan yang paling tinggi itu terjadi pada tahun 2016 dengan produk SR-008 dengan memperoleh dana sebesar 31,5 triliun rupiah dengan tingkat imbalan $8,30 \%$. Sedangkan grafik terendah terjadi pada tahun 2011 dengan produk SR-003 telah diterbitkan oleh pemerintah dan mendapatkan dana sebesar Rp. 7.34 Triliun dimana tingkat imbalan 8,15\% dan 2018 sebesar Rp. 8.43 triliun dengan mengeluarkan sukuk SR-010 dengan tingkat imbalan sebesar 5,90\%.

Investor menggunakan volume perdagangan untuk melihat bagaimana perkembangan sukuk yang diperdagangkan di pasar sekunder. Investor melakukan investasi untuk mencari keuntungan. Berikut ini merupakan faktor-faktor utama yang menentukan tingkat investasi adalah: tingkat keuntungan yang diramalkan akan diperoleh, suku bunga, ramalan mengenai keadaan ekonomi di masa depan, kemajuan teknologi, tingkat pendapatan nasional dan perubahan-perubahannya serta keuntungan yang diperoleh perusahaan-perusahaan (Sukirno, 2011:112). 
Di Indonesia penelitian mengenai sukuk sudah banyak diteliti, seperti penelitian yang dilakukan oleh Harahap (2018), mengenai faktor-faktor yang mempengaruhi sukuk negara ritel dengan menggunakan empat variabel makro ekonomi seperti, inflasi, suku bunga bank Indonesia, Produk Domestik Bruto (PDB), dan imbal hasil sukuk negara ritel dalam mempengaruhi harga sukuk ritel negara pada tahun 2011-2014. Penelitian yang dilakukan oleh Rahman dkk (2016) mengenai Pengaruh Harga Sukuk Negara Ritel Seri Sr-005, Tingkat Inflasi Dan Bi Rate Terhadap Tingkat Permintaan Sukuk Negara Ritel Seri Sr-005. Namun untuk penelitian tentang sukuk negara ritel pada saat terjadi pandemi dengan sebelum adanya pandemi masih jarang ditemukan. Naik turunnya permintaan sukuk ritel itu sendiri, yang dipengaruhi oleh berbagai faktor baik itu eksternal maupun internal, dalam penelitian kali ini penelitian berfokus pada pengaruh variabel makro ekonomi seperti inflasi, Bi Rate dan Kurs sebagai variabel pembandingnya yakni harga sukuk itu sendiri. Inflasi merupakan suatu kondisi ketika harga barang mengalami kenaikan harga dalam suatu level tertentu yang berdampak pada turunnya kekuatan mata uang suatu negara, ketika terjadi inflasi yang berdampak pada presentasi perubahan angka indeks yang mempengaruhi harga-harga konsumen yang akan berdampak pada turunnya performa dari sukuk ritel negara itu sendiri. Kemudian, Menurut Hermawan (2006), tingkat suku bunga menjadi salah satu indikator moneter yang berdampak pada kegiatan perekonomian sebab: (a) Tingkat suku bunga dapat berpengaruh terhadap keputusan investor yang akan berdampak pada tingkat pertumbuhan ekonomi, (b) Tingkat suku bunga juga berpengaruh terhadap keputusan pemilik modal dalam berinvestasi pada real assets atau financial assets, (c) Tingkat suku bunga juga akan berpengaruh terhadap usaha yang sedang dijalankan oleh pihak bank dan lembaga keuangan lainnya dan (d) Tingkat suku bunga dapat mempengaruhi nilai uang beredar. Nilai tukar dapat mempengaruhi aliran modal, sebab ketika aliran dana yang masuk ke dalam suatu negara banyak, maka permintaan atas mata uang negara tersebut akan bertambah, sedangkan jika lebih banyak dana yang dialirkan ke luar negeri akan menyebabkan nilai mata uang negara tersebut merosot disebabkan oleh tingginya nilai suku bunga dan return investasi di negara lain.

\section{KAJIAN LITERATUR}

Dari penelusuran literatur penelitian terdahulu terkait faktor-faktor yang mempengaruhi tingkat permintaan atas sukuk negara ritel pada saat pandemi covid-19 belum ditemukan bentuk penelitian yang langsung membahas tentang ini karena memang sukuk negara ritel termasuk produk yang baru diterbitkan mulai dari awal tahun 2009. Hanya terdapat beberapa penelitian terkait tentang sukuk yang dapat digunakan sebagai acuan dasar dalam penelitian ini :

Berdasarkan hasil analisis dan pembahasan yang telah dilakukan oleh Wafa (2010) bahwa harga sukuk negara ritel, harga obligasi ritel, tingkat bagi hasil deposito bank syariah, dan tingkat suku bunga mempunyai pengaruh yang signifikan terhadap tingkat permintaan sukuk negara ritel pada periode Maret 2009-Juni 2010. Secara parsial setiap variabel independen di atas mempunyai pengaruh secara signifikan terhadap tingkat permintaan sukuk negara ritel periode Maret 2009-Juni 2010. Dari segi perilaku investasi secara syariah, instrumen-instrumen investasi syariah yang diajukan dalam penelitian ini memiliki bobot yang lebih tinggi pengaruhnya pada pertimbangan perubahan permintaan sukuk dibandingkan dengan investasi pada instrumen investasi konvensional (Wafa, 2010).

Keberadaan sukuk ritel sangat mendukung usaha pemerintah untuk memperluas sumber pembiayaan negara maupun memperluas produk keuangan syariah. Sepanjang 10 tahun sejak diterbitkan pertama kali tahun 2009, permintaan sukuk ritel cukup tinggi yang menunjukkan minat masyarakat berinvestasi pada produk investasi ini sangat besar. Hasil penelitian menunjukkan bahwa BI rate berpengaruh negatif signifikan sementara harga sukuk ritel, inflasi dan tingkat bagi hasil deposito mudharabah tidak berpengaruh terhadap tingkat permintaan sukuk ritel SR-005 (Muhammad, et al., 2019) 
Rodoni \& Setiawan (2016) menyatakan tujuan dari penelitian yang telah ia lakukan untuk membandingkan tingkat risiko dan return obligasi dengan sukuk, menggunakan beberapa besaran perhitungan, yaitu yield to maturity (YTM), Macaulay's durasi, dan Value at Risk (VaR). Hasil penelitian ini menunjukkan bahwa tidak ada perbedaan signifikan antara obligasi YTM dan YTM sukuk yang diterbitkan. Menggunakan rumus durasi Macaulay untuk mengevaluasi durasi obligasi dan sukuk, penelitian menemukan bahwa tidak ada perbedaan yang signifikan dalam durasi obligasi dan sukuk. Namun, hasil perhitungan dan perbandingan VaR, menunjukkan perbedaan yang signifikan antara obligasi dan sukuk, demikian juga perbandingannya dari VaR kelompok sampel obligasi dengan kelompok sampel sukuk menggunakan sampel k uji. Namun dengan menguji masing-masing kelompok VaR dari kelompok sampel obligasi dan sampel sukuk kelompok, hasil tidak menunjukkan perbedaan yang signifikan.

Maza (2016) mengemukakan bahwa sukuk merupakan salah satu instrumen investasi yang memberikan peluang bagi investor Muslim dan non-Muslim untuk berinvestasi di Indonesia. Sehingga, sukuk dapat dimanfaatkan untuk membangun perekonomian bangsa dan menciptakan kesejahteraan masyarakat. Fakta selama ini menunjukkan bahwa pasar sangat responsif terhadap penerbitan sukuk. Hampir semua sukuk yang diterbitkan, diserap habis oleh pasar, bahkan pada beberapa kasus menimbulkan kelebihan permintaan. Dengan adanya sukuk, mereka memiliki alternatif investasi yang relatif aman dan return-nya cukup menggiurkan. Sebut saja misalnya sukuk Indosat, returnnya saat ini sebesar 16 persen. Bahkan, pada periode awal, return sukuk Indosat mencapai 17,82 persen. Kemudian untuk tantangan nya sendiri itu ada beberapa yaitu seperti sosialisasi yang belum cukup dan opportunity cost nya.

Hasil penelitian Mulyani \& Setiawan (2008) bahwa Sukuk ritel Negara mengalami pertumbuhan yang sangat baik dari pertama diterbitkan pada tahun 2009 dengan seri 001 permintaan masyarakat terhadap sukuk sangat baik dalam pertama penerbitan jumlah penerbitan sukuk mencapai nilai Rp.5.556.290 triliun dengan jumlah investor 14.295 jiwa hingga saat ini sukuk menjadi produk investasi yang terus mengalami kenaikan adapun total nilai penerbitan sukuk per 2019 dengan seri 011 mencapai Rp.21.117.570 dengan jumlah investor sebanyak 35.026 jiwa. jika dibandingkan dengan obligasi ritel Negara pertumbuhan sukuk ritel Negara memiliki pertumbuhan yang lebih lambat hal ini dilatarbelakangi oleh beberapa faktor diantaranya informasi produk, risiko investasi, kepuasan investasi dan kehalalan produk. Untuk dapat bersaing dengan instrumen investasi lainnya dimana faktor utama yang mendominasi terhambatnya perkembangan investasi pada produk sukuk ritel adalah kurangnya sosialisasi dan edukasi pemerintah terhadap masyarakat mengenai pentingnya investasi pada sukuk ritel Negara, oleh karena itu pemerintah harus lebih agresif dalam proses pemasaran produk, sehingga dengan teredukasinya masyarakat akan menarik investor untuk dapat menanamkan investasinya pada produk sukuk ritel Negara.

Penelitian yang dilakukan oleh Maftuh (2014) dengan judul Pengaruh Harga Sukuk Negara Ritel, Inflasi, BI Rate, Dan Tingkat Bagi Hasil Deposito Mudharabah Terhadap Tingkat Permintaan Sukuk Ritel SR 003. Penelitian tersebut menyatakan bahwa variabel independen harga sukuk negara ritel SR-003, tingkat inflasi, BI rate dan tingkat bagi hasil deposito mudharabah berpengaruh secara simultan terhadap variabel dependen tingkat permintaan sukuk negara ritel. Secara parsial variabel harga sukuk 51 negara ritel berpengaruh negatif signifikan terhadap tingkat permintaan sukuk negara ritel SR-003, sedangkan variabel lainnya tidak berpengaruh terhadap tingkat permintaan sukuk negara ritel SR-003.

Kemudian penelitian sejenis selanjutnya oleh (Mubarokah \& Rahma, 2019), tujuan penelitian ini adalah mengetahui faktor yang mempengaruhi permintaan Sukuk Ritel SR 05.Variabel yang diteliti dalam penelitian ini terbatas pada harga sukuk negara ritel, tingkat suku bunga deposito perbankan, nisbah bagi hasil deposito perbankan syariah, harga obligasi lain dan tingkat inflasi. Bentuk penelitian ini adalah deskriptif kuantitatif. Data yang digunakan dalam penelitian ini adalah data sekunder Metode analisis yang digunakan dalam penelitian ini adalah 
analisis regresi linear berganda.Hasil penelitian menunjukkan bahwa faktor yang mempengaruhi permintaan sukuk ritel seri SR 05 adalah harga sukuk itu sendiri.

Fuji (2015) mengatakan bahwa kenaikan nilai tukar rupiah terhadap USD yang bergantung kepada kenaikan suku bunga konvensional tidak mempengaruhi daya beli atau permintaan investor pada sukuk ritel 007. Karena berdasarkan teori yang ada, produk bursa efek yang menggunakan instrumen bunga (riba) seperti obligasi, jelas dilarang dalam Islam. Pada transaksi yang menggunakan instrumen bunga, return yang diberikan bersifat tetap, tanpa memandang kondisi keuangan perusahaan tersebut apakah ia rugi atau untung.

\section{Landasan Teori}

\section{Sukuk ritel Negara}

Sukuk ritel Negara dapat dipandang sebagai instrumen investasi yang mampu mempengaruhi pertumbuhan sektor ekonomi syariah, hal ini dikarenakan sukuk ritel mampu menghimpun dana investor individu (Handayani \& Surachman, 2017). Sukuk Ritel adalah Sukuk Negara yang dijual kepada individu atau orang perseorangan Warga Negara Indonesia melalui Agen Penjual dengan karakteristik minimal pembelian relative kecil (lima juta rupiah), jangka waktu yang pendek (tiga tahun), imbalan tetap, dan pembayaran imbalan setiap bulan.

Direktorat Jenderal Pengelolaan Utang Negara Departemen Keuangan menjelaskan sukuk ritel adalah surat berharga negara yang diterbitkan berdasarkan prinsip syariah sebagai bukti atas bagian penyertaan terhadap aset Surat Berharga Syariah Negara, yang dijual kepada individu atau perseorangan Warga Negara Indonesia melalui agen penjual, dengan volume minimum yang telah ditentukan (Rahman, et al., 2016)

Risiko memiliki sukuk Negara ritel (Kemenkeu, 2015) :

a. Resiko Gagal Bayar (Default Risk), adalah resiko dimana investor tidak dapat memperoleh pembayaran dana yang dijanjikan oleh penerbit pada saat produk investasi jatuh tempo. berhubung yang menerbitkan pemerintah, resiko ini sangatlah kecil (diasumsikan risk free).

b. Resiko Pasar (Market Risk), adalah potensi kerugian bagi investor (capital loss) karena menjual sukuk ritel sebelum jatuh tempo (pada saat nilainya turun).I

c. Resiko Likuiditas (Liquidity Risk), adalah kesulitan dalam pencairan, resiko ini bisa disebabkan karena kecenderungan produk syariah di-hold (tidak diperjual belikan hingga jatuh tempo), tetapi untuk sukuk ritel para agen penjual telah menjamin untuk membeli kembali barang yang dijual oleh investor. resiko yang bisa terjadi adalah investor terpaksa menjual kepada agen penjual dengan harga di bawah harga pasar. Apabila pembelian dalam jumlah tidak besar, bunganya yang relatif kecil dan ditransfer ke bank bisa menjadi tidak signifikan dan bisa terpakai.

\section{Inflasi}

Inflasi menurut Mankiw (2002) adalah: gejala kenaikan harga barang - barang dalam suatu level harga tertentu yang mengakibatkan turunnya kekuatan nilai suatu mata uang. Sedangkan menurut Blanchard (2000), inflasi adalah naiknya harga barang dan jasa secara umum dalam suatu level harga tertentu di dalam perekonomian dalam suatu periode tertentu. Inflasi biasanya menunjuk pada harga-harga konsumen, tapi bisa juga menggunakan harga-harga lain (harga perdagangan besar, upah, harga, aset, dan lain-lain) biasanya dipresentasikan sebagai presentasi perubahan angka indeks (Ahmad, 2011). 
Inflasi menurut Sukirno (2011:333) adalah kenaikan harga yang berlaku dalam suatu perekonomian. Indikator yang digunakan untuk mengukur inflasi adalah IHK (indeks harga konsumen). Dalam menghitung inflasi (Bella, 2018 ) bisa digunakan rumus sebagai berikut:

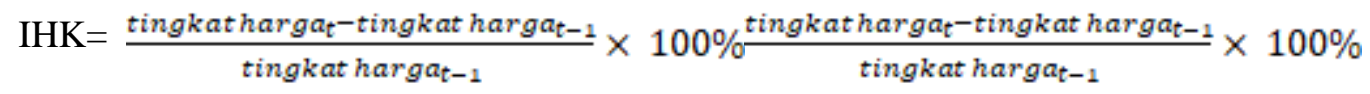

\section{BI Rate}

Menurut Bank Indonesia, BI rate adalah suku bunga kebijakan yang mencerminkan sikap atau stance kebijakan moneter yang ditetapkan oleh bank Indonesia dan diumumkan kepada publik. Bank Indonesia melakukan penguatan kerangka operasi moneter dengan mengimplementasikan suku bunga acuan atau suku bunga kebijakan baru yaitu BI 7-Day (Reverse) Repo Rate, yang berlaku efektif sejak 19 Agustus 2016, menggantikan BI Rate. Penguatan kerangka operasi moneter ini merupakan hal yang lazim dilakukan di berbagai bank sentral dan merupakan best practice internasional dalam pelaksanaan operasi moneter.

\section{Kurs}

Keynes mengemukakan sesuatu yang berbeda dengan teori moneter klasik. Pada hakekatnya perbedaan ini terletak pada penekanan oleh Keynes pada fungsi uang yang lain, yaitu sebagai store of value dan bukan hanya sebagai means of exchange. Teori ini kemudian terkenal dengan nama teori liquidity preference (Boediono, 2001: 7).

Nilai tukar rupiah adalah nilai yang menunjukkan jumlah mata uang dalam negeri yang diperlukan untuk mendapatkan satu unit mata uang asing. Nilai tukar yang digunakan dalam penelitian ini adalah nilai tukar rupiah terhadap USD.

\section{Pengembangan Hipotesis}

Berdasarkan penelitian terdahulu dan landasan teori yang digunakan yakni dalam penelitian ini ingin menguji beberapa jenis variabel yang mungkin mempengaruhi performa sukuk ritel negara dari indikator makroekonomi. Berdasarkan uraian tersebut, dihipotesiskan bahwa :

\section{Pengaruh Harga dan Performa Sukuk Ritel Negara sebelum dan saat terjadi Pandemi}

H1 : Harga Sukuk Ritel Negara berpengaruh negatif terhadap permintaan sukuk ritel sebelum terjadi pandemi dan berpengaruh positif saat terjadi pandemi

Menurut kamus bahasa Indonesia, harga adalah nilai suatu barang dan jasa yang diukur dengan jumlah uang yang dikeluarkan oleh pembeli untuk mendapatkan sejumlah barang atau jasa. Menurut (Laksana, 2008) Harga adalah jumlah uang yang diperlukan sebagai penukar berbagai kombinasi produk dan jasa, dengan demikian suatu harga haruslah dihubungkan dengan bermacam macam barang dan atau pelayanan, yang akhirnya akan sama dengan sesuatu yaitu produk dan jasa. Salah satu faktor pengambilan keputusan suatu investasi pada sukuk adalah harga per unit sukuk. Kurva permintaan obligasi memiliki kemiringan yang negatif, yang artinya ketika harga yang ditawarkan rendah maka permintaan obligasi akan mengalami kenaikan (Nurhaliza, 2018). 


\section{Pengaruh Inflasi dan Performa Sukuk Ritel Negara sebelum dan saat terjadi Pandemi}

$\mathrm{H} 2$ : Tingkat Inflasi berpengaruh negatif terhadap permintaan sukuk ritel sebelum terjadi pandemi dan berpengaruh positif saat terjadi pandemi

Inflasi memicu kenaikan harga barang dan jasa yang dapat menyebabkan daya beli riil masyarakat menjadi turun. Pada kondisi ini masyarakat akan cenderung mendahulukan kebutuhan pokok dibandingkan melakukan investasi termasuk membeli sukuk. Inflasi juga dapat menyebabkan return sukuk menjadi turun karena pendapatan riil yang diterima oleh investor tergerus oleh inflasi. Hal ini yang berimbas pada penurunan minat membeli sukuk sehingga tingkat permintaan sukuk akan turun. Penelitian yang dilakukan oleh N.N Karimah (2013) menyatakan tidak ada pengaruh inflasi, BI Rate kurs rupiah dan NAB Reksadana terhadap sukuk ritel.

\section{BI Rate dan Performa Sukuk Ritel Negara sebelum dan saat terjadi Pandemi}

H3 : BI Rate berpengaruh negatif terhadap performa sukuk ritel negara sebelum dan saat terjadi pandemi

Ketika seorang investor menanamkan modalnya pada saat suku bunga sedang tinggi dapat menyebabkan hilangnya kesempatan untuk memperoleh keuntungan yang lebih tinggi, sebaliknya jika investor menanamkan modal pada saat nilai dari suku bunga turun, hal tersebut dapat dilakukan ketika seorang investor mampu mengorbankan kesempatan untuk mendapat keuntungan dari bunga. Kenaikan BI rate akan diikuti oleh perkembangan suku bunga sertifikat Bank Indonesia (SBI) dan suku bunga simpanan di perbankan untuk menarik minat masyarakat menyimpan uang dibank. Tingkat bunga simpanan yang lebih tinggi dari return sukuk akan lebih memberi keuntungan bagi nasabah perbankan sehingga masyarakat akan cenderung menyimpan dananya di bank dibandingkan untuk membeli sukuk sehingga tingkat permintaan sukuk menjadi turun.

\section{Kurs dan Performa Sukuk Ritel Negara sebelum dan saat terjadi Pandemi}

H4 : Kurs berpengaruh positif terhadap performa sukuk ritel negara sebelum dan saat terjadi pandemic

Nilai tukar/kurs dapat mempengaruhi perkembangan pasar modal sebab fluktuasi nilai rupiah terhadap mata uang asing yang akan mempengaruhi investasi dalam negeri, khususnya investasi yang ada di pasar modal. Harga saham akan mengalami penurunan ketika nilai dari mata uang dolar naik dibandingkan dengan rupiah sebab perusahaan akan memiliki hutang dengan naiknya dolar AS. Kurniati (2007) menyatakan bahwa motif dari investor asing menanamkan modalnya di Asia dan Indonesia, dimana investor menaruh perhatian besar terhadap potensi pasar maupun stabilitas nilai tukar yang mencerminkan stabilitas finansial.. Mata uang yang menurun secara jelas akan mengurangi daya beli dari pendapatan dan keuntungan modal yang didapat dari jenis investasi apapun. 


\section{JURNAL AKUNTANSI, Vol. 10, No. 2, November (2021)}

\section{Kerangka Pemikiran}

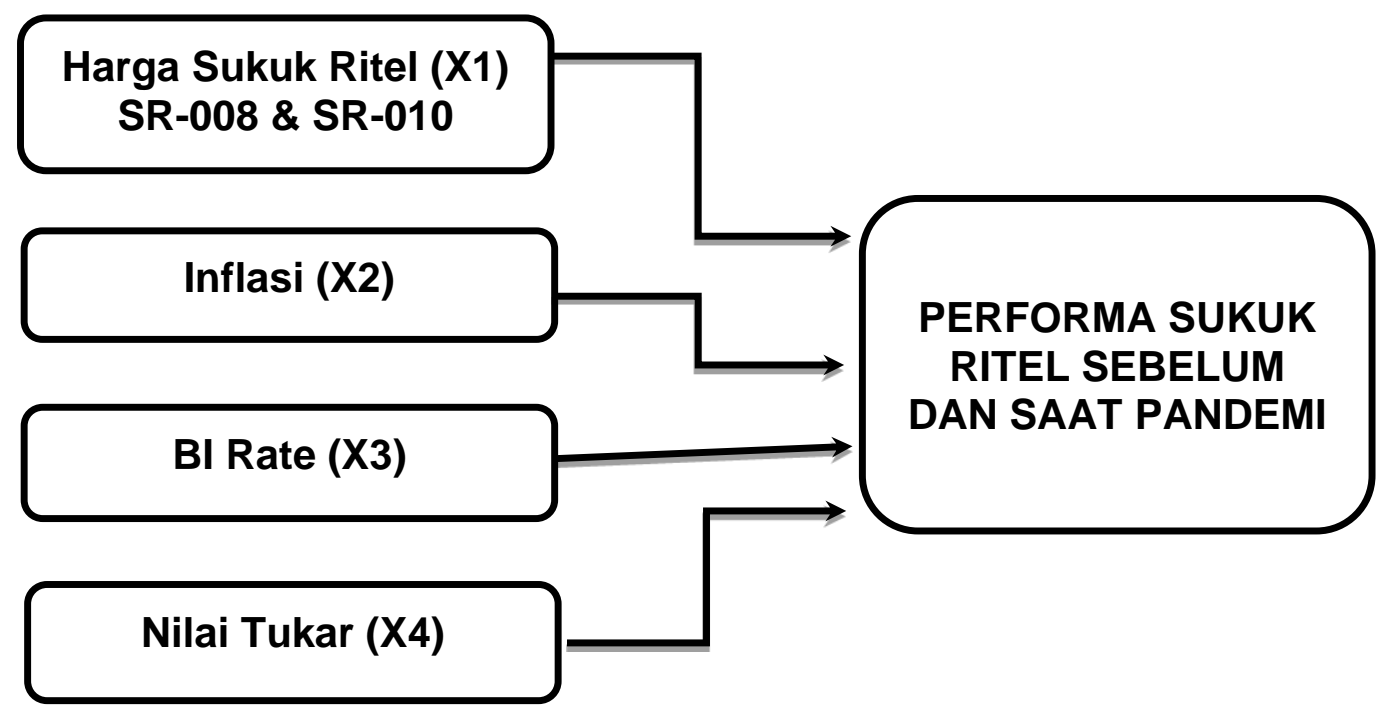

Gambar 1. Kerangka Pemikiran

\section{METODE PENELITIAN}

\section{Jenis Penelitian}

Penelitian ini menggunakan bentuk penelitian deskriptif kuantitatif. Metode deskriptif yaitu metode yang didasarkan pada analisis dengan pendeskripsian faktor-faktor yang berhubungan dengan masalah yang dimaksudkan sebagai pendukung untuk analisis metode kuantitatif.

\section{Objek Penelitian}

Objek penelitian ini adalah instrumen sukuk negara ritel yang jatuh tempo tenor nya sebelum terjadi pandemi yakni sukuk ritel SR-008 dan sukuk ritel negara yang jatuh tempo tenornya pada saat terjadi pandemi yakni SR-010

\section{Data dan Sumber data}

Data yang digunakan dalam penelitian ini berupa data sekunder (secondary data) yaitu data yang diperoleh dari pihak kedua, yang berupa laporan perkembangan secara nominal maupun prosentase dari setiap variabel bebas dan terikat yang telah ditentukan dalam hipotesis. Data Inflasi, Bi Rate serta Kurs periode 2016-2020 diperoleh dari web resmi Bank Indonesia yaitu www.bi.go.id serta web resmi Otoritas Jasa Keuangan yaitu www.ojk.go.id.

\section{Metode Analisis}

Analisis data yang digunakan dalam penelitian ini adalah menggunakan analisis model VAR (vector autoregressive) dan VECM (vector error correction model) yang diolah dengan program Eviews 10. Metode analisis yang digunakan dalam penelitian ini adalah analisis regresi data time series. Adapun prosedur analisis data adalah sebagai berikut: 
a. Analisis Normalitas Data

b. Analisis Stationaritas Data

c. Analisis Kointegrasi data

d. Analisis dan Estimasi Vector Autoregression

\section{HASIL DAN PEMBAHASAN}

\section{Hasil Analisis}

\section{Gambaran Umum Objek Penelitian}

Pada penelitian ini menggunakan data Sukuk Ritel Negara SR-008 dan SR-10 yang diterbitkan oleh pemerintah. SR-008 sendiri diterbitkan oleh pemerintah pada 10 Maret 2016 dengan tenor 3 tahun yang berarti jatuh temponya pada tanggal 10 maret 2019 dengan tingkat imbalan 8,30\% pertahun menggunakan akad Ijarah Asset to be Leased. Dan kemudian Sukuk Ritel Negara SR-010 yang diterbitkan oleh pemerintah pada tanggal 21 maret 2018 jatuh tempo pada 10 maret 2021 dengan tenor 2 tahun dan tingkat imbalan sebesar 5,90\% per tahun. Diterbitkan khusus untuk investor individu Warga Negara Indonesia (WNI). Pembelian sukuk dapat dilakukan melalui agen penjual sukuk yang telah ditetapkan oleh Menteri Keuangan melalui Direktorat Jenderal Pengelolaan Utang (DJPU). Agen Penjual sukuk terdiri dari perusahaan sekuritas dan perbankan.

\section{Uji Stasioneritas}

Uji Stasioneritas dilakukan dengan metode Augmented Dicky Fuller (ADF). Berdasarkan hasil uji stasioneritas dapat diketahui bahwa jika nilai absolute ADF lebih besar dari nilai MacKinnon pada tingkat signifikan 5\% maka tidak stasioner pada tingkat level.

Tabel 1. Hasil Uji Akar ADF

\begin{tabular}{|c|c|c|c|c|c|c|}
\hline \multirow[b]{2}{*}{ Variabel } & \multicolumn{3}{|c|}{ Level } & \multicolumn{3}{|c|}{ First Difference } \\
\hline & $\begin{array}{l}\text { Nilai } \\
\text { ADF }\end{array}$ & $\begin{array}{l}\text { Nilai Mc } \\
\text { Kinnon } \\
\text { sig 5\% }\end{array}$ & Keterangan & $\begin{array}{l}\text { Nilai } \\
\text { ADF }\end{array}$ & $\begin{array}{l}\text { Nilai Mc } \\
\text { Kinnon } \\
\text { sig 5\% }\end{array}$ & Keterangan \\
\hline $\begin{array}{c}\text { Harga SR- } \\
008\end{array}$ & -1.986711 & -2.887665 & $\begin{array}{c}\text { Tidak } \\
\text { stasioner }\end{array}$ & -13.65156 & -2.887665 & Stasioner \\
\hline $\begin{array}{c}\text { Harga SR- } \\
010\end{array}$ & -2.265604 & -3.020686 & $\begin{array}{c}\text { Tidak } \\
\text { stasioner }\end{array}$ & -4.501121 & -3.831511 & Stasioner \\
\hline Inflasi & -0.822930 & -2.914517 & $\begin{array}{c}\text { Tidak } \\
\text { stasioner }\end{array}$ & -6.911810 & -2.915522 & Stasioner \\
\hline BI Rate & -2.116160 & -2.915522 & $\begin{array}{c}\text { Tidak } \\
\text { stasioner }\end{array}$ & -5.513598 & -2.915522 & Stasioner \\
\hline Kurs & -2.680613 & -2.914517 & $\begin{array}{c}\text { Tidak } \\
\text { stasioner }\end{array}$ & -8.588082 & -2.915522 & Stasioner \\
\hline $\begin{array}{l}\text { Permintaan } \\
\text { Sukuk } \\
\text { Ritel 2016- } \\
2020\end{array}$ & -1.223763 & -3.065585 & $\begin{array}{c}\text { Tidak } \\
\text { Srasioner }\end{array}$ & -3.237031 & -3.081002 & Stasioner \\
\hline
\end{tabular}




\section{JURNAL AKUNTANSI, Vol. 10, No. 2, November (2021)}

\section{Penentuan Lag Optimum}

Lag optimum adalah jumlah lag yang diperkirakan untuk menghindari permasalahan autokorelasi maupun heteroskedastisitas. Penentuan panjang lag tersebut dimanfaatkan untuk mengetahui seberapa lama periode keterpengaruhan terhadap variabel dependen dengan waktu sebelumnya. Pemilihan panjang lag yang tepat dapat dilakukan dengan mempertimbangkan beberapa kriteria seperti Akaike Information Criterion (AIC), Schwarz Criterion (SC), dan Hannan-Quinn (HQ). Dalam hal ini, model yang akan digunakan adalah yang memiliki nilai AIC, $\mathrm{SC}$, dan HQ yang paling rendah di antara berbagai lag yang diajukan. Berikut hasil uji lag optimum adalah:

Tabel 2. Uji Lag Optimum

\begin{tabular}{|l|l|c|c|c|c|}
\hline \multirow{2}{*}{ Lag } & \multicolumn{5}{|c|}{ Kriteria } \\
\cline { 2 - 6 } & LR & FPE & AIC & SC & HQ \\
\hline 0 & - & $2.29 \mathrm{e}+23$ & -6.797928 & -6.82105 & -6.805468 \\
\hline 1 & 132.9974 & $5.77 \mathrm{e}+21$ & -6.427229 & -6.56600 & -6.472466 \\
\hline 2 & 44.20204 & $3.64 \mathrm{e}+21$ & -6.367509 & -6.62192 & -6.450443 \\
\hline 3 & 35.72430 & $2.49 \mathrm{e}+21$ & -6.290638 & -6.66069 & -6.411268 \\
\hline 4 & 15.11870 & $6.91 \mathrm{e}+21$ & -6.300741 & -6.78644 & -6.459069 \\
\hline 5 & $51.54077 *$ & & $-5.431216^{*}$ & $-6.03256^{*}$ & $-5.627241^{*}$ \\
\hline
\end{tabular}

Berdasarkan hasil pada tabel di atas diketahui bahwa nilai AIC terkecil sebesar 5.431216* pada lag 5. Dengan demikian lag optimum yang dihasilkan adalah 5 lag. Penentuan panjang lag juga digunakan untuk mengetahui stabilitas sistem VAR. Sistem VAR dikatakan stabil jika seluruh roots-nya memiliki modulus yang lebih kecil atau mendekati satu. Berdasarkan uji stabilitas lag juga diketahui bahwa seluruh roots-nya memiliki modulus yang lebih kecil atau mendekati satu.

Begitu pula dengan nilai Schwarz Criterion (SC) dan Hannan-Quinn (HQ) terkecil terletak pada lag 5 yaitu masing-masing $\mathbf{- 6 . 0 3 2 5 6 *}$ dan $\mathbf{- 5 . 6 2 7 2 4 1 *}$, dikarenakan banyaknya tanda asterik (*) berada pada lag 5 memenuhi persyaratan untuk dianalisis lebih lanjut yaitu berupa kointegrasi.

\section{Uji Kointegritas}

Pada penelitian kali ini menggunakan Johansen Cointegration Test dengan bantuan Eviews 10. Adapun Kriteria adanya kointegritas dapat dilihat dari nilai Trace Statistic. Apabila nilai Trace Statistic > Critical Value (5\%) maka terdapat kointegrasi, namun jika sebaliknya maka tidak terdapat kointegrasi. Berikut hasil uji kointegrasi :

Tabel 3. Uji Johansen Cointegration SR-008

\begin{tabular}{|c|c|c|c|}
\hline $\begin{array}{c}\text { Hypothesized no. } \\
\text { of CE(s) }\end{array}$ & Eigenvalue & Trace statistic & 0,05 Critical value \\
\hline None & 0.789782 & 133.1623 & 69.81889 \\
\hline At Most 1 & 0.690515 & 80.13561 & 47.85613 \\
\hline At Most 2 & 0.614568 & 40.25884 & 29.79707 \\
\hline
\end{tabular}


Dapat dilihat dari tabel tersebut bahwa nilai trace statistic 0 (none) sebesar $133.1623>$ critical value at 5\% yaitu 69.81889. Dengan demikian dapat dinyatakan terdapat 2 kointegrasi yang digunakan dalam penelitian ini. Adanya kointegritas ini dapat diartikan bahwa terdapat hubungan jangka panjang antar variabel yang digunakan dalam penelitian ini terhadap performa sukuk negara ritel SR-008. Kemudian dapat dilanjutkan untuk menggunakan metode VECM dan dapat menentukan estimasi VECM untuk SR-008 ini.

Selanjutnya yaitu uji kointegritas pada sukuk negara ritel SR-010 apakah dalam indeks ini terdapat hubungan jangka panjang antar variabel atau tidak.

Tabel 4. Uji Kointegritas SR-010

\begin{tabular}{|c|c|c|c|}
\hline $\begin{array}{c}\text { Hypothesized no. of } \\
\text { CE(s) }\end{array}$ & Eigenvalue & Trace statistic & 0,05 Critical value \\
\hline None* & 0.829980 & 79.92717 & 69.81889 \\
\hline At Most 1 & 0.737586 & 46.26218 & 47.85613 \\
\hline At Most 2 & 0.508670 & 20.84340 & 29.79707 \\
\hline At Most 3 & 0.309510 & 7.341268 & 15.49471 \\
\hline At Most 4 & 0.015901 & 0.304547 & 3.841466 \\
\hline
\end{tabular}

Dapat dilihat dari tabel tersebut bahwa nilai trace statistic 0 (none) sebesar 79.92717 > critical value at 5\% yaitu 69.81889. Dengan demikian dapat dinyatakan terdapat 1 kointegrasi yang digunakan dalam penelitian SR-010.

\section{Estimasi VECM}

Hasil estimasi dengan VECM diperoleh koefisien jangka panjang dan jangka pendek. Berikut ini ditunjukkan hasil estimasi VECM jangka panjang yaitu:

Tabel 5. Hasil Estimasi VECM Jangka Panjang Antar

Variabel Terhadap Performa Sukuk Negara Ritel

\begin{tabular}{|c|c|}
\hline Cointegrating Eq: & CointEq1 \\
\hline Permintaan Sukuk (-1) & 1.000000 \\
\hline \multirow{2}{*}{ BI_RATE(-1) } & 0.009317 \\
\cline { 2 - 2 } & {$[1.82448]$} \\
\hline \multirow{2}{*}{ INFLASI(-1) } & -0.008244 \\
\cline { 2 - 2 } KURS(-1) & {$[-1.10081]$} \\
\cline { 2 - 2 } & -1.06280 \\
\hline \multirow{2}{*}{ Harga Sukuk(-1) } & {$[-0.13193]$} \\
\cline { 2 - 2 } & $-3.280,453$ \\
\hline C & {$[-6.63676]$} \\
\hline
\end{tabular}




\section{JURNAL AKUNTANSI, Vol. 10, No. 2, November (2021)}

Berdasarkan hasil estimasi VECM jangka panjang diatas dapat diinterpretasikan sebagai berikut:

a. Nilai koefisien BI Rate sebesar 0.009317, hal ini menunjukan bahwa BI Rate berpengaruh positif terhadap performa sukuk negara ritel 008. Apabila variable lainnya diasumsikan bahwa setiap kenaikan 1 satuan harga sukuk ritel SR-008 maka performa sukuk ritel akan naik sebesar 0.009317 .

b. Nilai Koefisien Inflasi sebesar -0.008244 , hal ini menunjukan bahwa tingkat inflasi berpengaruh negatif terhadap performa sukuk ritel negara SR-008, setiap kenaikan 1 satuan inflasi performa sukuk ritel SR-008 akan maka performa sukuk ritel akan turun sebesar 0.008244 .

c. Nilai Koefisien Kurs sebesar -1.06280, dapat dilihat bahwa Kurs berpengaruh negatif terhadap performa sukuk ritel, dilihat bahwa setiap kenaikan 1 satuan kurs maka performa sukuk ritel akan turun sebesar 1.06280

d. Nilai koefisien harga Sukuk sebesar -3.280,453 berpengaruh negatif terhadap tingkat performa sukuk negara ritel. Apabila variabel lainnya diabaikan atau dianggap tetap maka setiap kenaikan harga sukuk, tingkat performa sukuk negara ritel akan turun sebesar 3.280,453.

\section{Analisis Impulse Response Function (IRF)}

Analisis IRF memberikan informasi tentang indikator volume yaitu kecepatan atau berapa waktu lag yang dibutuhkan untuk merespon perubahan dan kekuatan variabel lain.

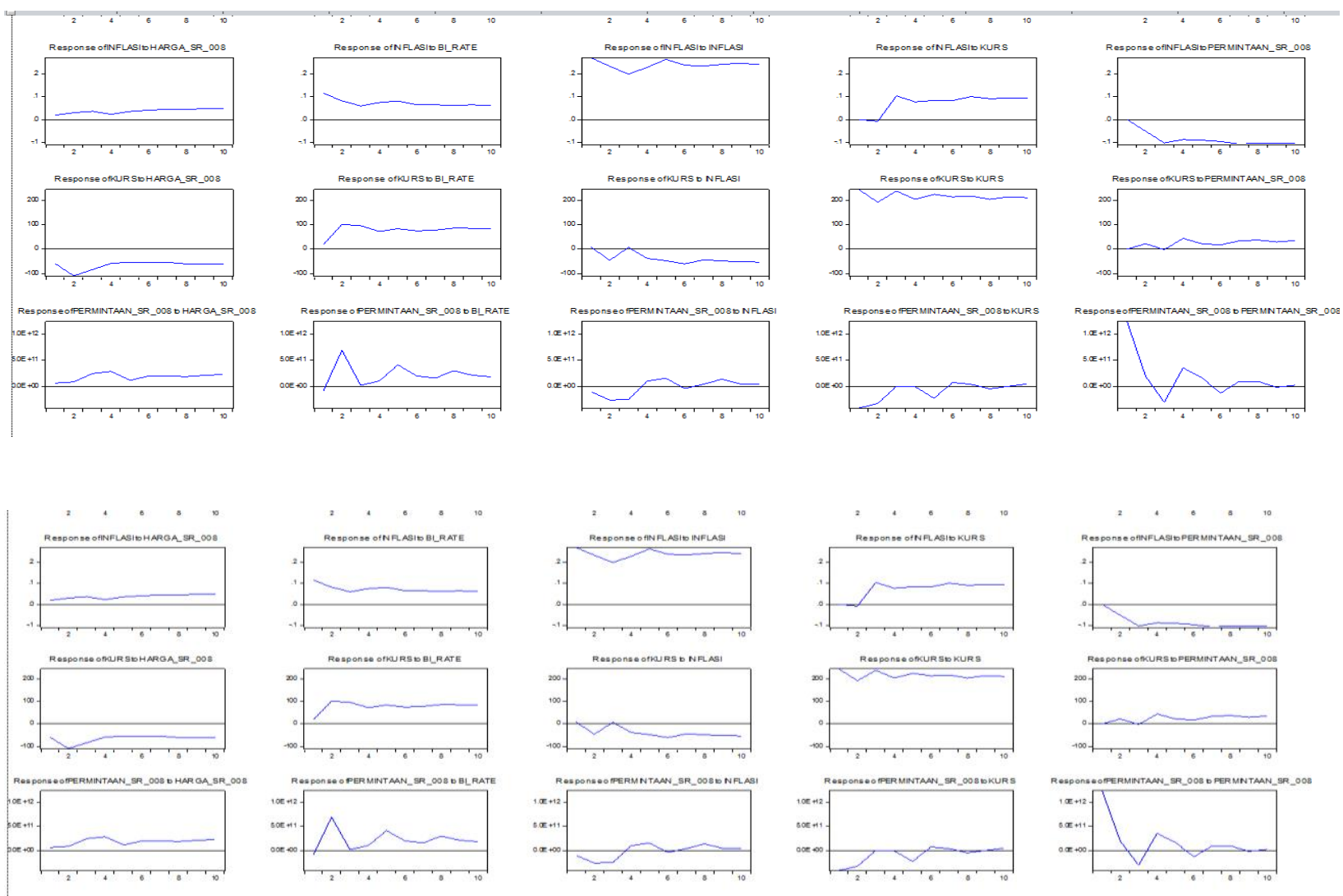




\section{JURNAL AKUNTANSI, Vol. 10, No. 2, November (2021)}

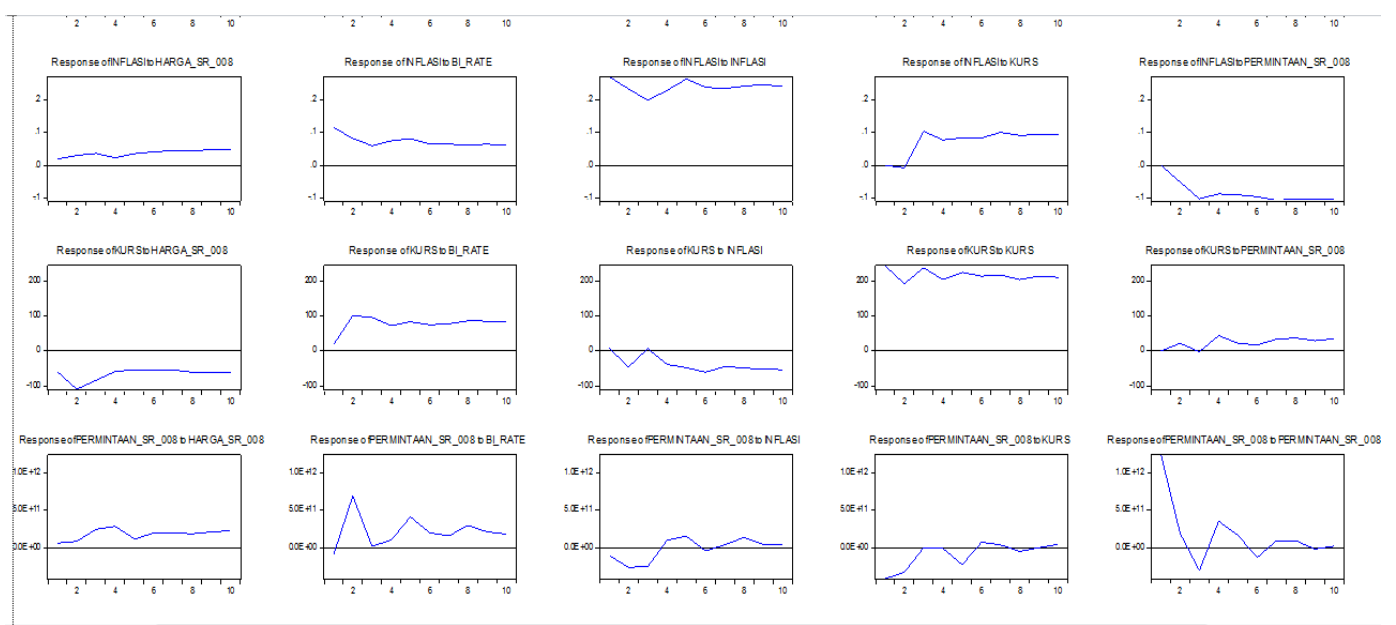

Gambar 2. Impulse response function

Sumber: Output Eviews 10 diolah, 2021

\section{Analisis Variance Decomposition}

Informasi yang disampaikan oleh FEVD adalah mengenai proporsi dari pergerakan atau pengaruh shock pada sebuah variabel terhadap variabel lainnya pada periode saat ini dan yang akan datang (Ajija, 2011:168) Dari tabel diketahui bahwa kontribusi terbesar yang mempengaruhi performa sukuk ritel adalah Harga dari sukuk itu sendiri.

Tabel 6. kontribusi yang mempengaruhi performa sukuk ritel

\begin{tabular}{|c|c|c|c|c|c|c|}
\hline Period & S.E. & Harga & BI_RATE & INFLASI & KURS & Permintaan \\
\hline 1 & 0.150451 & 57.37088 & 42.62912 & 0.000000 & 0.000000 & 0.000000 \\
\hline 2 & 0.272540 & 73.70205 & 21.70439 & 4.406731 & 0.169864 & 0.016973 \\
\hline 3 & 0.348495 & 78.59228 & 18.44606 & 2.756593 & 0.161847 & 0.043215 \\
\hline 4 & 0.450243 & 80.89185 & 16.44340 & 2.401004 & 0.237612 & 0.026142 \\
\hline 5 & 0.555527 & 81.67360 & 15.98165 & 1.840100 & 0.481241 & 0.023407 \\
\hline 6 & 0.637040 & 77.65709 & 20.29942 & 1.487138 & 0.533183 & 0.023172 \\
\hline 7 & 0.721926 & 75.12517 & 22.33606 & 1.412968 & 1.104089 & 0.021719 \\
\hline 8 & 0.816442 & 73.23408 & 24.18001 & 1.232487 & 1.334542 & 0.018880 \\
\hline 9 & 0.939343 & 74.11130 & 22.81220 & 1.116815 & 1.945272 & 0.014414 \\
\hline 10 & 1.056996 & 73.53073 & 22.26621 & 1.742163 & 2.449338 & 0.011560 \\
\hline & & & & & & \\
\hline
\end{tabular}

Sumber : Output Eviews 10 diolah, 2021 


\section{JURNAL AKUNTANSI, Vol. 10, No. 2, November (2021)}

\section{Uji Beda Sebelum dan Saat Pandemi}

Tabel 7. Paired Samples Statistics

\begin{tabular}{|rl|c|c|c|c|}
\hline & & Mean & N & Std. Deviation & Std. Error Mean \\
\hline Pair 1 & Sebelum & 4661280619047,619 & & & \\
& Pandemi & 21 & 9000861690820,40000 & 1964149048476,79470 \\
& Saat Pandemi & 2917238095238,095 & & & \\
& 0 & 21 & 3955855329821,37650 & 863238404152,42650 \\
\hline
\end{tabular}

Tabel 8. Paired Samples Test

\begin{tabular}{|c|c|c|c|c|c|c|c|c|c|}
\hline & & \multicolumn{5}{|c|}{ Paired Differences } & \multirow[t]{3}{*}{$\mathrm{t}$} & \multirow[t]{3}{*}{ df } & \multirow{3}{*}{$\begin{array}{l}\text { Sig. (2- } \\
\text { tailed) }\end{array}$} \\
\hline & & \multirow[t]{2}{*}{ Mean } & \multirow[t]{2}{*}{$\begin{array}{c}\text { Std. } \\
\text { Deviation }\end{array}$} & \multirow[t]{2}{*}{$\begin{array}{l}\text { Std. Error } \\
\text { Mean }\end{array}$} & \multicolumn{2}{|c|}{$\begin{array}{l}\text { 95\% Confidence } \\
\text { Interval of the } \\
\text { Difference }\end{array}$} & & & \\
\hline & & & & & Lower & Upper & & & \\
\hline $\begin{array}{c}\text { Pair } \\
1\end{array}$ & $\begin{array}{c}\text { Sebelum } \\
\text { Pandemi } \\
\text { - Saat } \\
\text { Pandemi }\end{array}$ & $\begin{array}{r}174404252 \\
3809,5240 \\
0\end{array}$ & $\begin{array}{r}101322793 \\
16410,691 \\
00\end{array}$ & $\begin{array}{r}221104461 \\
5708,9243 \\
0\end{array}$ & $\begin{array}{r}286811572 \\
4833,1016 \\
0 \\
\end{array}$ & $\begin{array}{r}635620077 \\
2452,1490 \\
0\end{array}$ & ,789 & 20 & ,439 \\
\hline
\end{tabular}

Berdasarkan tabel diatas dapat diketahui bahwa harga sukuk ritel SR-008 dan SR-010 pada saat pandemi dan sebelum terjadi pandemi menunjukkan perbedaan sebesar 1,74404E+12 dimana nilai dari sebelum pandemi lebih tinggi 4,66128E+12 dibandingkan dengan saat terjadi pandemi yakni sebesar 2,91724E+12. Namun, hasil uji nilai statistik yang diperoleh signifikan terlihat dari hasil perhitungan t statistik yang menunjukkan bahwa Sig (2-tailed) sebesar 0,439 lebih besar dari nilai signifikansi 0,05 . Sehingga dalam penelitian ini dapat diketahui bahwa tidak terdapat perbedaan yang signifikan antara performa sukuk ritel negara sebelum dan saat terjadi pandemi.

\section{PEMBAHASAN}

\section{Pengaruh Harga Sukuk terhadap performa Sukuk Ritel Negara sebelum dan saat terjadi Pandemi}

Dari hasil penelitian yang telah dilakukan menunjukan bahwa terdapat pengaruh yang cukup signifikan dalam jangka pendek maupun jangka panjang antar variabel harga terhadap performa sukuk ritel negara itu sendiri. Hal ini sesuai dengan hukum permintaan yang menyatakan semakin tinggi harga suatu barang maka semakin sedikit permintaan terhadap barang tersebut. Hal ini disebabkan sukuk ritel negara itu dijamin oleh pemerintah. Salah satu faktor yang mempengaruhi tingginya tingkat permintaan terhadap sukuk negara ritel seri tersebut dikarena keuntungan yang diberikan dibandingkan dengan produk lain. Faktor regulasi juga dianggap mempengaruhi tingkat permintaan terhadap sukuk negara ritel seri (Mubarokah \& Rahma, 2019). 


\section{Pengaruh BI Rate terhadap performa Sukuk Ritel Negara sebelum dan saat terjadi Pandemi}

Berdasarkan hasil uji yang telah dilakukan, bahwa BI Rate memiliki pengaruh positif dan signifikan terhadap performa sukuk ritel negara pada saat sekarang. Hal ini disebabkan suku bunga atau BI Rate cenderung stabil pada 3,75\%. Kondisi ini mengidentifikasikan bahwa perekonomian Indonesia cenderung stabil dan dapat meningkatkan performa sukuk ritel negara kedepannya. Dikarenakan suku bunga juga merupakan sebuah harga yang menghubungkan masa kini dengan masa depan, yang ditentukan oleh jumlah permintaan dan penawaran. Harahap (2018), menyatakan jika suku bunga naik maka harga sukuk negara ritel akan turun sedangkan jika suku bunga turun maka harga sukuk negara ritel akan naik. Pada saat suku bunga BI (BI rate) turun maka dipastikan harga sukuk negara ritel akan naik dan kemungkinan para pemilik deposito akan mencairkan depositonya dan beralih ke obligasi pemerintah seperti ORI dan Sukuk Negara Ritel.

\section{Pengaruh Inflasi terhadap performa Sukuk Ritel Negara sebelum dan saat terjadi Pandemi}

Sukanto (2009) menjelaskan bahwa tingkat inflasi dibedakan menjadi tiga jenis yaitu ringan ( $<10 \%$ setahun), sedang (10\%-30\% setahun), dan berat (30\%-100\%) yang masing-masing memiliki pengaruh yang berbeda. Berdasarkan hasil uji estimasi VECM, dalam jangka panjang inflasi memiliki pengaruh negatif dan signifikan terhadap peningkatan performa sukuk ritel negara. Dengan tingkat inflasi yang masih bisa dikendalikan dan stabil, maka kondisi perekonomian negara juga stabil, sehingga investor akan tertarik untuk berinvestasi dalam sukuk, hal ini akan menyebabkan volume perdagangan sukuk akan meningkat. Sehingga ketika terjadi inflasi maka jumlah permintaan akan investasi sukuk ritel negara akan menurun sebesar koefisien yang telah dijelaskan sebelumnya.

\section{Pengaruh Kurs atau Nilai Tukar terhadap performa Sukuk Ritel Negara sebelum dan saat terjadi Pandemi}

Tingkat Kurs dalam penelitian ini tidak berpengaruh secara signifikan dengan hasil kurs yang bersifat negatif yang menunjukan bahwa dalam jangka panjang nilai tukar berpengaruh secara signifikan terhadap performa sukuk ritel negara. Dapat diketahui nilai kurs dalam jangka panjang dapat menjadi acuan dalam performa sukuk ritel negara, ketika suatu negara memiliki kondisi ekonomi yang stabil, maka dapat mendorong investor untuk berinvestasi dalam sukuk ritel negara ini. Hasil penelitian yang dilakukan oleh Ni'mah (2019) menunjukkan bahwa dalam jangka panjang terdapat pengaruh yang signifikan dan positif antara variabel nilai tukar terhadap volume sukuk SR-007. Hal itu menunjukkan bahwa negara tersebut memiliki kondisi ekonomi yang relatif baik, sehingga dapat mendorong investor untuk berinvestasi dalam sukuk.

\section{PENUTUP}

\section{Simpulan}

Berdasarkan analisis data dan pengujian hipotesis yang telah dilakukan, maka dapat ditarik kesimpulan Variabel harga sukuk negara ritel untuk hasil estimasi VECM jangka panjang memiliki koefisien -3.280,453 berpengaruh negatif terhadap tingkat performa sukuk negara ritel. Apabila variabel lainnya diabaikan atau dianggap tetap maka setiap kenaikan harga sukuk, tingkat performa sukuk negara ritel akan turun sebesar 3.280,453. Artinya, setiap perubahan harga sukuk dapat mempengaruhi keputusan investor untuk berinvestasi pada sukuk ritel negara. 


\section{JURNAL AKUNTANSI, Vol. 10, No. 2, November (2021)}

Variabel BI Rate untuk hasil estimasi VECM jangka panjang memiliki koefisien sebesar 0.009317 dan t-hitung 1.82448 hal ini menunjukan bahwa BI Rate berpengaruh positif dan signifikan terhadap performa sukuk negara ritel. Artinya, setiap perubahan BI Rate akan mempengaruhi keputusan investor untuk berinvestasi pada sukuk negara ritel SR-008.

Variabel Inflasi dalam hasil estimasi VECM jangka panjang memiliki pengaruh negatif dengan angka koefisien sebesar -0.008244, hal ini menunjukan bahwa tingkat inflasi berpengaruh negatif terhadap performa sukuk ritel negara, yang artinya variabel inflasi akan mempengaruhi minat investor dalam berinvestasi di sukuk negara ritel pada saat terjadi pandemi.

Variabel Kurs dalam hasil estimasi VECM menunjukan bahwa kurs berpengaruh negatif terhadap performa sukuk ritel negara dengan angka koefisien sebesar-1.06280, yang artinya variabel kurs mempengaruhi keputusan dan jika nilai kurs turun makan dapat mendorong investor untuk berinvestasi dalam sukuk negara ritel, sehingga performa sukuk ritel negara akan meningkat.

\section{Saran}

Pada penelitian ini masih terdapat banyak kekurangan baik itu dari struktur penulisan maupun kelengkapan data pada variabel sukuk ritel negara SR-010 diharapkan untuk peneliti selanjutnya dapat menambahkan kekurangan data tersebut dan dapat menambahkan variabel lainnya seperti Harga Obligasi lain, PDB, SBIS dan lainnya yang berpengaruh terhadap performa sukuk ritel negara di Indonesia.

\section{REFERENSI}

Ahmad, Z. M. 2011. Pengaruh Indikator Makroekonomi Terhadap Besarnya Jumlah Zakat Yang Terkumpul Di Lembaga Amil Zakat Dompet Dhuafa Republika. 1-113.

Al-Arif, M. Nur Rianto. 2011. Dasar-Dasar Ekonomi Islam. Solo: Pt Era Adicitra Intermedia.

Blanchard. 2000. Economics, Prentice Hall International, Inc.,New Jersey.

Boediono. 2001. Ekonomi Makro (Sari Sinopsis Pengantar Ilmu Ekonomi No2) Edisi Keempat. FPFE Yogyakarta

Gumilang, Reshinta Candra, R. Rustam Hidayat Dan Maria Goretti Wi Endang Np. 2014. Pengaruh Variabel Makro Ekonomi, Harga Emas Dan Harga Minyak Dunia Terhadap Indeks Harga Saham Gabungan (Studi Pada Bursa Efek Indonesia Periode 2009-2013). Jurnal Administrasi Bisnis (Jab) Vol. 14 No.1.

Laksana, F. 2008 . Manajemen Pemasaran Pendekatan Praktis. Graha Ilmu, 208.

Handayani, D., \& Surachman, E. N. 2017. Sukuk Negara As Financing Strategy For Rene-Wable Energy Infrastructure: Case Study Of Muara Laboh Geothermal Power Project. International Journal Of Energy Economics And Policy, 7(4), 115-125.

Harahap, M. I. 2018 . Analisis Faktor Yang Memengaruhi Minat Investor terhadap Sukuk Negara Ritel. J-EBIS, 3(1), 1-57.

Hutapea, Ganda, Elvania Margareth Dan Lukas Tarigan. 2014. Analisis Pengaruh Kurs Us/Idr, Harga Minyak, Harga Emas Terhadap Return Saham (Studi Kasus Pada Bei Periode 2007-2011). Buletin Ekonomi Vol. 18 No. 2.

Kurniati, Y., Prasmuko, A \& Yanfitri. 2007. Determinan FDI (Faktor-faktor yang Menentukan Investasi Asing Langsung). Working Paper WP/06/2007. Bank Indonesia. 
Maza, R. EL. 2016. Peluang dan tantangan obligasi syari'ah dalam penerbitannya. JEBI (Jurnal Ekonomi Dan Bisnis Islam, 1(1), 53-65.

Mubarokah, I., \& Rahma, M. 2019. Analisis Faktor Yang Mempengaruhi Permintaan Sukuk Ritel Seri Sr 05. Profit: Jurnal Kajian Ekonomi Dan Perbankan Syariah, 3(2), 1-21. https://doi.org/10.33650/profit.v3i2.860

Muhammad, R., Permana, E. N., \& Nugraheni, P. (2019). Tingkat Permintaan Sukuk Ritel: Analisis Faktor Internal Dan Eksternal. Media Riset Akuntansi, Auditing \& Informasi, 19(2), 249. https://doi.org/10.25105/mraai.v19i2.4205

Muhammad Maftuh. (2014). Pengaruh Harga Sukuk Negara Ritel, Tingkat Inflasi, Bi Rate, Dan Tingkat Bagi Hasil Deposito Mudharabah Terhadap Tingkat Permintaan Sukuk Ritel Sr 003. Skripsi

Mulyani, R., \& Setiawan, I. (2008). Sukuk Ritel Negara, Instrumen Investasi Halal Untuk Membangun Negeri. Iqtisadiya: Jurnal Ilmu Ekonomi Islam.

N. Gregory Mankiw., 2002, Makroekonomi, Edisi 6, Penerbit Erlangga, Jakarta.

Ni'mah, L. F. (2019). Analisis Pengaruh Harga Sukuk Negara Ritel Seri Sr-007, Yield, Nilai Tukar, Tingkat Bagi Hasil Deposito Mudharabah, BI Rate, dan Inflasi terhadap Volume Perdagangan Sukuk Negara Ritel Seri SR-007. Skripsi : Fakultas Ekonomi UIN Maulana Malik Ibrahim Malang, 2019, 1-17.

Nurhaliza, Suri. (2018). Analisis Faktor-faktor yang Mempengaruhi Permintaan Sukuk Negara Ritel SR 007 di Indonesia (Periode 2015 - 2017). Skripsi

NURUL KARIMAH N.N 2013. ANALISIS FAKTOR-FAKTOR YANG MEMPENGARUHI TINGKAT SPREAD HARGA (MARKET VALUE DAN INTRINSIC VALUE) PADA SUKUK RITEL INDONESIA (STUDI KASUS http://digilib.uin-suka.ac.id

Otoritas Jasa Keuangan, 2018.

Pratiwi, Fuji. 2015. Penerbitan Sukuk Dolar Dinilai Positif. Republika (Syariah), Jakarta : 19 Desember, 2015.

Rahman, F., Paminto, A., \& Nadir, M. 2016. Pengaruh Harga Sukuk Negara Ritel Seri SR-005, Tingkat Inflasi dan BI RATE terhadap Tingkat Permintaan Sukuk Negara Ritel Seri SR005. Jurnal Manajemen, 8(1), 19-29.

Rodoni, A., \& Setiawan, A. 2016. Risk and Return: Bonds and Sukuk in Indonesia. Al-Iqtishad: Journal of Islamic Economics, 8(2), 255-270. https://doi.org/10.15408/aiq.v8i2.3159

Sukirno, Sadono. 2011. Makroekonomi Teori Pengantar (Edisi 1, Cet. Ke-20). Jakarta: Rajawali Pers.

Wafa, M. A. K. 2010. Analisa Faktor-Faktor Yang Mempengaruhi Tingkat Permintaan Sukuk Ritel-I. La_Riba, 4(2), 161-178. https://doi.org/10.20885/lariba.vol4.iss2.art2 